\title{
Perilous Life Views: Suicide, Morality and the Rise of the Individual in May Fourth China
}

\author{
Rune Svarverud \\ University of Oslo ${ }^{1}$
}

\begin{abstract}
Individualism, imported as an intellectual current from the West, entered the Chinese discourse during late imperial times in the late nineteenth and early twentieth centuries. The early Chinese interpretation and representation of individualism was closely related to ideas of China's national survival in what was perceived as a Darwinian battle for survival between nations. During the May Fourth Movement starting in 1919, individualism for many prominent intellectuals took on new perspectives, interpreting the individual as an ultimate end of political and social life. With the introduction of Marxist thought and the rise of socialism as a political movement individualism was, however, again in China attached to collective interests related to society at large, to nation and to the world community of socialism.

The aim of this article is to focus on interpretations of the individual, on the morality and the social responsibilities of the individual, in a Chinese debate on suicide around the May Fourth

1 Short versions of this paper have been presented at the conference "The Rising Individual and Changing Moral Practice in Contemporary China," UCLA, May 2008 and at the 17th EACS conference in Lund, August 2008. I am grateful for comments and suggestions from the discussants and audiences to the initial versions of this paper.
\end{abstract}


Movement in 1919. By focussing on the debate on the rights and wrongs of suicide, I hope to be able to show how notions of the individual and his or her relationship to family and society at this time carried connotations from the early forms of individualism in China as well as bearing witness of the growing interest in the social theories of Marxism to become so prominent in the decades to come. I intend to show that the May Fourth period contains different interpretations of the individual and individual morality and that these interpretations may be attached to different generations of intellectuals in China at this time. My interpretation of this debate will show that individualism was a very strong current among student intellectuals in China around 1919. That current was, however, short-lived as the teacher generation of intellectuals during the May Fourth, prominently concerned with collective social and political questions, dominated the period to come when Socialism gained momentum as the main intellectual current in the 1920s and '30s.

Keywords: China, suicide, May Fourth Movement, modernity, enlightenment, individualism, morality, autonomy, loyalty, socialism, Marxism.

(...) Then, if this is the meaning of freedom, does that mean that freedom may not be practised by the individual? No, what kind of talk is that? Collective freedom is the accumulation of individual freedom. The individual may not leave the collective and exist on his own, and if the collective is not able to protect its freedom then there will be other collectives coming from the outside to infringe on, suppress and seize this collective. And then, what about the freedom of the individual? (Liang Qichao 1998: 104).

We are familiar with the complex processes by which individualism and ideas about the free, self-directing and autonomous but also socially interrelated, interdependent, and ethically accountable individual were introduced into China, partly via Japan, by intellectuals such as Liang Qichao (梁啟超) (1873-1929), Yan Fu (嚴復) (1854-1921), Du Yaquan (杜亞泉) (1873-1933) and others from the late nineteenth century; and we recognize the seminal role 
which individualism, as a Western intellectual current, played in the culture of the May Fourth Movement (see for instance DoleželováVeligerová and Král [eds.] 2001; Huang 1972; Lydia Liu 1995: $77-$ 99; Schwarcz 1986). This focus on the autonomous and independent individual stands out in stark contrast and opposition to traditional, Confucian interpretations of the individual, where "the Confucian concern for the individual self's moral/spiritual growth carries a strong collective perspective, specified in the individual's obligations to the collectives of family, state and world" (Chen 2007: 3). In 1907 Lu Xun (魯迅) described the controversial connotation of the term 'individual' as it was applied in the discourse of early twentieth century China: "The term geren [or 'individual'] entered China only within the last few years, but has already fast become the butt of ridicule and debasement by those among our scholars who are purported to understand the world and keep abreast of the times" ( $\mathrm{Lu}$ Xun in "Wenhua pianzhi lun" [文化偏至論], translated by Lydia Liu in Liu 1995: 85). The individual had in the early twentieth century inescapably entered the intellectual discourse as an agent of political and social change, both as the ultimate end and basis for social and political change - to some intellectuals - and as the greatest obstacle to social cohesion and responsibility - to others. In the decades following the May Fourth Movement in 1919, individualism in China largely turned towards interpreting individual emancipation in the framework of the larger collective - the nation, the state, and the world of communism - under the banner of Chinese Marxism. Xiaoming Chen argues that "the May Fourth individualist awakening was actually a reason for at least some of the May Fourthians' interest in and conversion to Marxist communism" (Chen 2007: 7). He argues further that Guo Moruo (郭沫若) (1892-1978), Li Dazhao (李大釗) (1889-1927), Qu Qiubai (篗秋白) (1899-1935) and many of their contemporary May Fourth intellectuals turned to Communism precisely because of their quest for individual emancipation (Chen 2007: 5-9). The May Fourth intellectual culture represents a short but nevertheless seminal period in the Chinese interpretation of the concept of the individual between its introduction in the early twentieth century, and the Marxist interpretation of individual autonomy and morality in the 1920s and 1930s (and of course the total demise of individualism as an intellectual current in the decades to 
follow). The May Fourth culture represents by no means a unified interpretation of the individual, but contains intellectual elements from and links to both China's Confucian tradition, to the early modern Chinese emphasis on the individual's role in safeguarding national interests, as well as to the political ideas heralding the advent of Marxism in China. The question I intend to address in this article is whether the options and assignments of the rising individual during the May Fourth Movement were confined to theoretical deliberation and debates on questions about nation, struggle, national survival, popular enlightenment, changing family and gender relations, and common welfare in China, where we are mostly familiar with the Chinese notion of geren (個人); or if the individual as an autonomous and independent agent also entered the personal sphere and agenda when questions about acute social realities of near family or friends, life and death, were pushed to the forefront. Suicide is evidently one of the issues that in such a way urges those involved to search their minds and souls for reasons and explanations of tragic events, and in this context brings forth ideas related to individual autonomy, independence, freedom, conduct, and morality. My aim in this paper is not primarily to analyze how ideas of the individual and individualism per se were interpreted in May Fourth China, but hopefully to be able to contribute to an understanding of how these ideas were expressed, integrated and applied in the public discourse when other urgent social topics were on the agenda. Debates on the individual act of suicide seem particularly apt to disclose the position on the morality and autonomy of the individual in China at this time. When raising questions about suicide in modern China in this article, my aim is thus not to study suicide as a social phenomenon, but rather to use the debates prompted by a number of cases of suicide around May fourth, 1919, as a starting point for examining changing notions of individual autonomy and morality as conceived by different generations of intellectuals in China at this time. Through this approach I hope to be able to probe behind the immediate ideological discourse on geren, individualism, social responsibility and morality in early Republican China.

The May Fourth in 1919 and the New Culture Movement represent a period in China of great political and ideological significance. Socialism was taking shape as a more mature political framework for 
China (Dirlik 1989; Chen 2007), and many Chinese intellectuals were struggling, in different ways, to disentangle their role attached to the state, reinterpreting their role in the Chinese enlightenment and their importance for the modernisation of Chinese society. ${ }^{2}$ The intellectual debates taking shape in a flourishing new landscape of periodicals and newspapers all over China epitomise the drive for change and revolution from below. These reforms were principally political and social in nature but they were also questioning human nature itself in radical ways, as well as the nature of human relations, and the nature of the relationship between state, society and humans (such as the emerging concept of citizenship ${ }^{3}$ ). The New Culture Movement is often characterised by an emphasis on the individual and his agency, most prominently present in the fiction of the period. My approach in this article is, however, not to study the representations of the individual in fiction. I want to be able to show how ideas of an autonomous individual varied among different generations and positions in the social and political discourse, and I wish to be able to convince my readers that a study of the discourse on suicide in May Fourth China is a fruitful device for interpreting the complex picture of attitudes towards individual agency, morality and social duties in the complex intellectual landscape in China at this time.

2 It should be remembered that many of the terms used for describing and labelling the May Fourth and the social, intellectual and political transformations taking place in urban China at this time, such as "modernity", "enlightenment", "renaissance", "movement", were at the time terminological loans and social, political and cultural ideas imported from the West and taking on particular meanings and connotations in China. When using such terms in describing these events and transformations in China, we should take care not to assume that they refer to the same phenomena and intellectual currents as they do in a European cultural and political context (See for instance Lee 2001; Sun 2008; Wagner 2001). Others again have argued that modernity, or rather modernisation, as it unfolded in late Qing China, most notably in the years following the 1898 reform period, powerfully informed the modernity, however incomplete or imperfect, that is most often associated with the May Fourth Movement. (See the various contributions to Karl and Zarrow [eds.] 2002).

3 For studies of the emerging concept of citizenship in late Qing and early Republican China, see the various contributions to Imagining the People: Chinese Intellectuals and the Concept of Citizenship, 1890-1920 edited by Joshua A. Fogel and Peter G. Zarrow (Fogel and Zarrow [eds.] 1997). 


\section{Suicide, individualism and modernity}

The relationship between suicide, religious belief, social change and modernity has been described and studied from different disciplinary angles and perspectives. A number of studies argue that traditionalism and the extended family have historically been the main sources of low suicide rates. It is claimed that in traditional societies the individual had a strong sense of belonging and could rely on the family when dealing with many of the ordeals of life. The line of argumentation is often that loose social structures and family relations, marriage for love, economic independence of the individual, individual employment, urbanisation, and schooling are factors related to modernity which seem to contribute to looser integration of the individual into social structures and consequently lead to higher suicide rates. Émile Durkheim argued that "the more integrated a person was into society, the less chance of suicide" (Simpson and Conklin 1989: 946).

Durkheim argued further that "the social disapproval of suicidal conduct increased constantly from ancient times to the present" and that "such increased disapproval was generated by the growing emphasis put on the dignity and sacredness of the individual." Durkheim claimed that "the condemnation of suicidal conduct was therefore essentially moral and it expressed the strong reaction of the collective conscience against the offences to the cult of the individual" (Marra and Orrù 1991: 273). Durkheim indicates that according to his observations the steadily growing emphasis on the individual in (European) societies has caused society to take collective moral action against offences to the individual as an idea. Marra and Orrù, in their study, have convincingly argued against the idea that social disapproval of suicide has increased in Europe when studying the long historical lines from ancient times to the present. They argue that "Durkheim's claim that increased disapproval of suicide accompanied increased consideration for the dignity of the individual is shown to be unfounded" (Marra and Orrù 1991: 273). They show that rather than representing a constant development from social approval of suicide towards condemnation, the attitude towards suicide in classical Greece, ancient Rome, and medieval and modern Europe has been a cyclical development of tolerance and aversion. In fact, they argue, 
suicide is an act directly affirming the ultimate value of individual freedom and dignity as such, while social disapproval of suicide may represent a collectivistic reaction against the autonomy of the individual and not a confirmation of "the dignity and sacredness of the individual," as Durkheim claimed.

It may be argued that a development from approval to condemnation of suicide is the main line of change over time in China, similar to the development that Durkheim has observed in European history - a development from social acceptance of suicide under particular circumstances in traditional China, to a debate arguing in favour of the dignity of the individual in the wake of modernity in China. The introduction of "the cult of the individual" into modern China has, similarly to the European debate, contributed to two different positions. One of these positions takes the dignity of the autonomous individual as the primary value, and attaches ultimate freedom of choice to the individual, also in cases of suicide. The other position takes a collectivistic attitude towards the cult of the individual by assigning collective moral condemnation to offences against the collective individual on behalf of each individual, thus contributing to collective condemnation of suicide. I shall in the following argue that the development from approval towards condemnation was indeed not linear with the rapid unfolding of intellectual modernity in early twentieth century China, where the collectivistic interpretation of individuality contributed to interpretations of the morality of suicide alongside interpretations of the ultimate value of individual autonomy and freedom. Before discussing the representations of individualism in modern China, we shall take a short look at traditional forms of and attitudes towards suicide in China as a backdrop for the changes in early twentieth century China.

\section{Suicide in traditional China}

In China both Confucianism and Buddhism have articulated strong collective condemnations against suicide. Nevertheless, suicide in traditional China has often been tolerated and rationalized as an act of 
escaping personal tragedy, sin and shame. ${ }^{4}$ Social relations, family ties, and morality in traditional $\mathrm{China}^{5}$ are indeed related to the development of Confucianism, and partly Buddhism and Daoism, as political and social philosophies. Attitudes towards suicide in traditional China were, however, only indirectly related to these philosophical traditions, while directly related to traditional ethics of family and society in China. The morality of the individual in traditional society is primarily not a matter of individual choice but most often attached to the individual as part of social structures and hierarchies which supersede the narrow structures of family and clan. We find therefore that attitudes towards suicide in traditional China often reflect ethics of relations between individual and collective at various levels of society.

Suicide in traditional China was never ritualized in a way similar to the tradition of seppuku or harakiri in Japan. ${ }^{6}$ Suicide has nevertheless in China in many situations been regarded as an act of courage and integrity directed at maintaining the respect and dignity of the individual (in his afterlife) and his family. Under certain circumstances, confronted with the established moral code of honour, suicide was even regarded as the only desirable and respectable choice left to the person involved. A failure to act in the appropriate way at these critical moments may indeed have resulted in a socially strongly undesirable situation for the individual as well as his or her family.

4 For a discussion of sin and shame related to suicide in traditional China, see Eberhard 1967.

5 Traditional or ancient China in this context refers to the philosophy and textual evidence of life and society in China from the pre-Qin and Han times down to the introduction of intellectual current from the West in the second half of the nineteenth century. It is evident that there was no such thing as one single tradition in ancient China and that attitudes towards life, death and suicide varied between the different schools of thought and levels of society. One also has to keep in mind that when using these sources to discuss social phenomena such as suicide, the sources that exist today are a result of a process of historical selection where extant sources represent the correct or accepted way of perceiving morality rather than a true representation of practice. Therefore, one has to be careful not to assume that these sources give us a nuanced or authentic representation of ideas about suicide in ancient China.

6 Even if it may be argued that the origin of these traditions is to be found in China's ancient past. 
A man's entire conception of himself was thus at stake at this critical moment. If he considered himself a man of high integrity and unblemished honour, and yet failed to comply, he might even come to doubt his own identity (Lindell 1973: 175).

Kristina Lindell has shown that none of the early Chinese philosophers held that one should commit suicide for the sake of loyalty to one's superior, for instance a son's filial piety towards his father (xiao tr). $^{7}$ Rather, the practice of preferring suicide as a way of retaining one's respect may be read from stories about honourable men and women in the early Chinese literary, historical and philosophical sources. These stories indicate that men often committed suicide when confronted with dilemmas of loyalty, situations where the choice between alternative actions invariably would lead to some sort of violation of loyalty. Men were most often bound by loyalty towards one's agnatic clan and towards one's lord in serving the state. Ideally, a man's loyalty to his lord should take precedence over loyalty to his family. ${ }^{8}$ A woman was in addition also bound by loyalty towards her husband's agnatic clan, often taking precedence over her loyalty to her own kin. "Most of the stories concerning suicides by women found in the classics are connected with their married status" (Lindell 1973: 221). Suicide was therefore often the only honourable way out of loyalty conflicts for both men and women. In addition, we see from these sources that the act of suicide could save one's family in cases where a man inevitably would be sentenced to capital punishment. If the man were permitted to commit suicide, the family would not be persecuted, whereas an execution of a convicted criminal often involved the execution of the entire family. The consequence was often that the person who chose suicide would be held in high esteem, sometimes even by the ruler

7 It may be argued that some of the early "Daoist" philosophers, such as Zhuangzi (who in fact only questionably may be identified with the Daoists as such), held that death was to be regarded as a relief from the burdens of human life. One never finds arguments in favour of suicide, however.

8 Hsieh and Spence have, however, shown that also men, in particular in Ming and Qing times, in many cases committed suicide because of circumstances related to family interrelationships (Hsieh and Spence 1981: 35-39). 
who had pronounced the death sentence, and the family would be spared.

In sum, it would be a misconception to claim that suicide was encouraged or even socially permissible in a general sense in ancient China and East Asia. Suicide in China was, however, sanctioned in cases where the person was confronted with moral dilemmas, and the act under these circumstances was regarded as dignified and honourable. "The idea that suicide was the only proper way to solve specific moral dilemmas was part of the Chinese formal moral code till modern times" (Lindell 1973: 237).

\section{Suicide and modernity in China}

Studies of the practice of suicide and conceptions of virtue and morality in general, in particular when it comes to the lives, marriages and (self-)deaths of women, in China between Han times and the modern era ${ }^{9}$ reveal that the practices described by Lindell changed considerably with political, social and intellectual changes in premodern, "traditional" China as well. ${ }^{10} \mathrm{I}$ do not intend in this paper,

9 In intellectual history most commonly indicating the period following Western intellectual impact upon China in the early decades of the twentieth century.

10 Analysed in articles such as "Suicide and the Family in Pre-modern Chinese Society" by Andrew C.K. Hsieh and Jonathan D. Spence (Hsieh and Spence 1981), "Female Virtue and the State in China" by Mark Elvin (1984) and in the various contributions on female suicide in Ming and Qing China in the special issue of the periodical Nan Nü 3:1 (2001) entitled Passionate Women: Female Suicide in Late Imperial China. Varying social, political and cultural factors contributed to changing interpretations of female chastity and morality (often relating to Cheng Zhu Neo-Confucian views on life and death in some way or another) in Ming and Qing times, and no general scholarly consensus has been reached about the causes, meanings and significance of female suicide in this period (Ropp 2001: 3). Janet Theiss has made a detailed study of female suicide related to what she refers to as "disgraceful matters", cases of violation of female chastity, and finds that in the historical material from eighteenth century China that forms the basis of her study, it is difficult to identify a consistent pattern of individual reactions to violations of the chastity of women. Whether they chose suicide or not, questions of personality, moral integrity, virtuous reputation (of the person and the family), and even her own chaste intent were the matter at stake when their chastity had been compromised (Theiss 2004: 
however, to discuss questions about the tradition of suicide among men and women in China in more detail but rather specifically to look into the debates on the changing relationship between individual and society, also into questions about morality, independence, and autonomy of the individual, related to cases of suicide in the May Fourth Era, the early phase of what Lindell refers to as "modern times" in China.

As we have discussed above, suicide was traditionally in China not presented or described as an act of the (free) choice of the individual but in most cases seen as the outcome of careful considerations of moral options and ethics of virtue vested in the individual by family, kin and society at large. Mark Elvin refers to "standard of honours" which "can critically determine an individual's sense of identity and self-esteem to the extent that if these standards cannot be maintained, he or she may prefer death to an existence with a social personality that is no longer, in some sense, viable" (Elvin 1984: 150). It appears that in historical cases when someone related a suicide to the loss of "personality", this "personality" of the person often refers to a social and morally defined individual and not to suicide as an individual act of free choice. It should, however, be taken into consideration that the historical sources available to us are concerned mainly with morally sanctioned cases of and reasons for suicide. Cases of non-sanctioned suicides, individuals who take their own lives for reasons other than those related to loyalty, chastity, martyrdom etc., will often not have been related nor included in the historical sources of pre-modern times. I am thus in this paper not implying that individuals in "traditional" China did not commit suicide out of personal anxiety, psychological distress or even morally unsanctioned behaviour. Weijing Lu has in her book on female chastity and the female maiden

192-209; Theiss 2001). Weijing Lu has deepened our understanding of the female cult of chastity in late imperial China through her analysis of the faithful maiden cult in late imperial China. She argues that rather than acting as suppressed and victimized women whose moral standards were set and maintained by the Confucian literati, the maiden who stayed loyal to her fiancé after his death, either when refusing to remarry or because she chose to follow her fiancé in death, mark a cult of female resolve that defies traditional interpretations of female insignificance in late imperial historical change $(\mathrm{Lu}$ 2008). 
cult in fact identified, often in between the lines in the various literary and historical sources, many of the moral dilemmas, conflicting motivations and mental struggles confronting young women in profound personal crisis (Lu 2008). These questions were, however, typically not on the agenda in the (largely male dominated) writings and literature in China before the absolute valorisation of the individual was stressed with the advent of the May Fourth and the New Culture Movements. ${ }^{11}$

An article in the June 1917 issue of The Eastern Miscellany (Dongfang zazhi 東方雜誌) entitled "Reasons for Suicide and Ways to Prevent Them" ("Zisha zhi yuanyin yu qi fangzhi zhi fa" 自殺之原因與其防止之法) signed by Yuzhi (愉之) ${ }^{12}$ substantiates our initial claim that suicide prior to the particular cases in 1918-19 that I shall discuss below was both in terms of causes and moral arguments primarily understood and related to relations in the family and cases of mental illness (Yuzhi 1917). When individuals committed suicide unrelated to these traditional explanations for taking one's own life, prior to the May Fourth period, the act was most often analysed and explained in terms of emulating the heroic acts of historical martyrs, such as in the article "A Debate on Why Suicide is Not an Appropriate Solution for Men of Ambitions" ("Lun zisha fei zhishi suo yichu” 論自殺非志士所宜出) reprinted from Zhongwai ribao (中外日報) in The Eastern Miscellany in November 1906 (Anonymous 1906).

Questions about free choice and individual option inevitably became topics for the debate on and interpretation of suicide during the socio-political discourse of the May Fourth, affirmed in articles such as the analysis of the causes for suicide among youth in China published in The Eastern Miscellany in December 1921 with the title “Suicide among Youth” (“Qingnian zhi zisha” 青年之自殺) signed by Jian Meng (健孟) (Jian Meng 1921). At this time, Chinese society experienced growing suicide rates ${ }^{13}$ in all walks of life, among

11 See for instance the leading article in Shenbao July 10, 1881 entitled “Neglecting Life" ("Lun qingsheng”論輕生).

12 The text consists mainly of translations from one of more American articles on this topic. The author Yuzhi (愉之) is here most probably the editor of The Eastern Miscellany Hu Yuzhi (胡愈之).

13 Figures of suicide rates in the major Chinese cities such as Beijing and 
intellectuals and young students, as well as related to more "traditional" cases of young women evading unwelcome marriage and civil servants confronted with loyalty dilemmas. Beginning with this May Fourth literature, both fiction and the socio-political discourse give ample evidence of the growing awareness of suicide as an indicator of the ills of society and the worsening psychological conditions for the individual in society. Suicide becomes an important topic for sociological analysis in May Fourth China. That sociological analysis is, however, not the main focus of this article.

In this paper we shall see that a few cases of suicide among intellectuals and students in May Fourth China brought into the open what we may identify as three different positions in the debates on individual morality and the freedom and autonomy of the individual in relationship to society. The first of these positions, which I will call the loyalty-position, may be identified with subordination of the individual to the causes and interests of traditional family and society, the ruling imperial court, Confucian teachings and ethics, a hierarchical society and the subordination of women in a patriarchal society. This position is most often attached to a traditional interpretation of the intellectual in China, running prior to the New Culture Movement when the singular individual fulfilled his social and political role in a loyalty-position to his superiors. The second position, which I shall call the collectivist-position, belongs to a liberal reformist tradition in modern China that identifies the autonomous individual as the foundation of society, but argues that individual options and the freedom of the individual are only protected and secured by focussing on the welfare and security of society at large. This position is often found in the writings of early advocates of liberalism, Social Darwinism and socialism in China, in the period from the early years of the twentieth century, as exemplified in the quotation from Liang Qichao's Xinminshuo (新民說), written in 1902-03, at the outset of this article, but is also

Shanghai were published from about 1907 and showed increasing rates. (Qi Weiping 1998: 49, Zheng Qingpo and Li Zidian 2005: 160) These figures may not represent exact figures but they do most probably correctly reflect a tendency in the change of suicide rates and they most certainly were perceived as such in early twentieth century China. 
current in the debates throughout the intellectual history of modern China. The third position, which I shall identify as the individualistposition, is a radical and new position most often associated with the literature of the May Fourth and the New Culture Movements and takes the freedom and autonomy of the individual as an absolute value in interpretations of morality, social responsibility and the options and agency of the individual. We shall in the following see that these three positions dominate the various interpretations of the rights and wrongs of suicide in China around 1919. I shall show that the intellectual climate in relation to these matters was not entirely dominated by an individualist-position; neither is a common vision of the intellectual climate of the May Fourth. Loyalist and collectivist-positions also contributed to the discourse on morality, autonomy and suicide in early twentieth century China, confirming the assumption made above that both collectivistic and individualistic interpretation of individuality contributed to interpretations of the morality of suicide in modern China. It should also at this point be reiterated that this paper is concerned with the arguments brought forth through these cases of suicide, also prompted by the perceived rise in suicide rates; and not with an analysis of the causes and changes in actual practice as such.

Vera Schwarcz has in her analysis of the May Fourth enlightenment described the differences between three generations of intellectuals struggling to make sense of China's situation and the road ahead in the second decade of the nineteenth century. The older generation of intellectuals are brought up under traditional Confucian learning, and reinterpret tradition to meet the political, social and intellectual challenges around 1919. The second generation of intellectuals, the first generation to cast off the "burden" of traditional learning and learn from intellectual currents pouring into China from the West and Japan, contests the conservative worldview of their fathers and becomes the first driving force of the Chinese enlightenment. This generation of intellectuals revolts against their own background and upbringing in traditional scholarship, but is still often struggling to confront and criticise tradition in fundamental ways. This generation becomes teachers and professors in the Western disciplines of science in the universities being established in China, most notably Beijing University, which becomes the breeding ground for the intellectuals of the May Fourth Movement. At Beijing 
University, this generation of intellectuals gathered around the publication of the periodical Xin qingnian (新青年, New Youth), which became their main vehicle for intellectual discourse. The third generation of intellectuals are the students at these universities. Even if only ten-odd years younger than their teachers, this generation of May Fourth intellectuals have no experience with traditional learning and Confucian family values, and are much more aware of the need for thorough mind reforms in order to bring about radical change in China. These students founded the periodical Xinchao (新潮, New Tide) in 1919, the periodical that became their most important channel for venting their views and frustrations with China and Chinese society throughout the May Fourth period. These two groups of intellectuals in May Fourth China managed at times to bridge the generational gap between themselves, but most often we find that their views and solutions for China differ quite radically (Schwarcz 1986: 67-76). We shall in the following see that this generational gap coincides with the various positions regarding freedom and morality of the individual in relation to society in the debates on suicide.

A number of well-known cases of suicide in early twentieth century China are related to political and social situations perceived to compel or cause individuals to end their lives in despair or protest. Among the most well-known examples we find Chen Tianhua (陳天華), who committed suicide in December 1905 in protest against regulations prohibiting individual students from studying in Japan. Yao Zhen (姚楨) is also said to have committed suicide in anxiety and protest, by throwing himself into the Huangpujiang in Shanghai, after he had failed to set up a university in China in the wake of the expulsion of Chinese students from Japan. In the 1920s we are familiar with a number of individuals who committed suicide related to similar social and political circumstances. On June 20, $1921 \mathrm{Yi}$ Baisha (易白沙) committed suicide because of his failure to realise his ideals in professional and social life. The author Wang Yiren (王以仁) committed suicide in 1926 because of failures in career and family life. Qing loyalist and Qinghua professor Wang Guowei (王國維) is known for having drowned himself in Kunming Lake in Beijing in June 1927 because of the final end to Qing and imperial life 
in the Forbidden City in Beijing, ${ }^{14}$ and because Chiang Kai-shek's republican troops were gaining control over North China. A number of instances of women committing suicide in the early decades of the twentieth century also attracted attention among intellectuals in China. The most well known of these cases is probably the suicide of Zhao Wuzhen (趙五貞) on November 14, 1919, which prompted Mao Zedong to publish a series of articles discussing the position of women in Chinese society.

\section{The debate on the suicide of Liang Ji}

I shall, however, not specifically discuss gender questions and the role of women in the family and society related to these debates on morality and the individual in May Fourth China. My purpose in this article is to analyse how perceptions of the relationship between individual and society, of morality and the effects of modernity on youth in China, came to be raised and debated in the wake of two cases of suicide around the May Fourth Movement in 1919. The first of these is the case of Liang Ji (梁濟, style: Juchuan 巨川) (18591918), the father of Liang Shuming (梁漱溟) (1893-1988), who committed suicide by throwing himself into the Jishuitan (積水潭) Lake in Beijing on November 10, 1918. His suicide was reported in the newspapers and periodicals throughout China, but these short reportages on his death, if not followed by an analysis of the causes and effects, on the significance and moral consequences of his act, are of less interest for our analysis. A series of articles in the periodical Xin qingnian in 1919, however, discussed and analysed the circumstances revolving around, and the significance of, the suicide of Liang Ji. The main article is entitled “On Suicide" (“Lun zisha”論自殺) and signed Tao Lugong (陶履恭), the pen name of Tao Menghe (陶孟和) (1887-1960). Tao's article in the January 15 issue of Xin qingnian is followed by a short and less analytical article by Chen Duxiu (陳獨秀) (1879-1942), entitled "Some Thoughts on the Suicide of Liang Juchuan" ("Duiyu Liang Juchuan xiansheng zisha zhi 
ganxiang” 對於梁巨川先生自殺之感想). Then, in the April 15 issue of Xin qingnian, Liang Ji's son Liang Shuming published an open letter addressing Chen Duxiu and Tao Menghe entitled "The Suicide of Mr. Liang Juchuan" ("Liang Juchuan xiansheng de zisha" 梁巨川先生的自殺). Liang's letter is also followed by a short commentary by $\mathrm{Hu}$ Shi (胡適) (1891-1962) representing the editors of Xin qingnian. As late as 1925, Xu Zhimo (徐志摩) (1896-1931) also wrote an essay entitled “On Suicide" (“Lun zisha” 論自殺), addressing the issues surrounding Liang Ji's suicide.

Liang Ji was a renowned writer in early republican China and an ardent royalist and a Qing loyalist, belonging to the elder generation of intellectuals experiencing the China of the May Fourth. In fact, he had in his writings already announced his suicide, and declared that the legacy of his act of suicide was to be recognized as a call for people to wake up against the republican government in support for the traditional Chinese imperial political legacy. In this article entitled “A Warning to the People" (“Jinggao shiren”敬告世人), which Liang Ji wrote one month prior to his suicide, he makes clear to his readers his commitment to the Manchu court, to traditional learning and propriety, and to the ancient sages:

Today I declare earnestly to the people of this generation that Liang Ji's death is an act of loyalty to the Qing. Because I lived my life towards the end of the Qing dynasty I declare that my deed is a loyalty act to the Qing. In fact, it is not because I take the Qing court as the most important. It is because I take the teachings of my youth as the primary. What I learned in my youth to take as the principles of my duties for my life was the poetry, the propriety, the ethics and lives of the Chinese ancient sages of thousands of years; the legacy and teachings of the forefathers and foremothers of my family. These principles are deeply imprinted in my brain and that is why I take these as my primary task. And that is why I cannot but sacrifice my life for them. Today people are moved by new speech and they sacrifice their own authority. From the last days of the emperors Guang[xu] and Xuan[tong] the new speech labels the emperor and kings as slaves, and those who simply receive their wages blindly follow them and forget their own life stories (Liang Ji quoted in Chen Duxiu 1919: 19). 
Liang Shuming goes a long way towards explicating his father's radical thinking during his younger years, and towards praising his father's contribution to the intellectual and educational reforms of late Qing times. Liang Shuming excuses his father for his conservative attitudes towards new activism in republican China and maintains that his father's conservative loyalty to tradition and the Manchus only started five to six years before his suicide (Liang Shuming 1919: 429431), making an effort to bridge the gap between these two generations of Chinese intellectuals at this time of crisis. Liang Ji's own position in terms of his self-proclaimed suicide in November 1918 was, in spite of his son's attempts to depict him as a reformist in his youth, clearly interpreted by most of his contemporaries as of the traditional kind, claiming devotion to traditional ideas of loyalty suicide (to the Qing) (xun Qing chao 殉清朝). It becomes clear to us, when reading Liang Ji's own declaration, that through his own suicide he proclaims allegiance to traditional ways of subordinating one's own life to the greater political cause of the emperor and the imperial court, which I have called the loyalty-position. Wang Guowei's comparable loyalty suicide in 1927 shows that this traditional way of subordinating one's life to the cause of the imperial state, also displayed in explicit terms by Liang Ji, outlived the intellectual and sociological currents of the May Fourth and New Culture Movements among the elder generation of intellectuals. Liang Ji's praise of traditional ethics and the Manchu court and his condemnation of the republican government were, however, denounced by many of the younger generation of politically active and sociologically informed contemporaries. They reveal quite contrary views on the individual and his loyalty to political elites. Tao Menghe, belonging to the teacher generation at Beijing University, is the first to present his position to the readers of the Xin qingnian in January 1919. Tao had studied geography and history in Japan in his early years and later left for London to engage in studies of sociology and economy.

It was as a sociologist and professor at Beijing University that Tao Menghe argues that Liang Ji's suicide is based upon a major misconception of the Manchu court, which did not represent the will of the people, but only the authority of a ruling elite and an outdated political culture. By committing suicide in loyalty to the Qing, Liang 
Ji willingly, as a loyal servant, offered his life not for a (just) cause but for the ruler and the political authority that he once served. According to Tao Menghe, the moral question that this raises is, however, not related to the way or the fact that Liang Ji chose to end his own life, but to the social implications of the idea that his life could be used as a warning and a wake-up call for the people of his generation (Tao Menghe 1919: 12-13). Tao Menghe argues from the sociological perspective that every individual has full autonomy over his own life and thus the freedom to end his or her life at any time and for any reason whatsoever. "Suicide is purely an individual act, and no one can make ethical judgements regarding its approval or condemnation" (Tao Menghe 1919: 15). This philosophical principle of complete autonomy of one's own life is in itself without moral implications. A suicide may, however, involve others and thus have social implications.

The result of a suicide is that one life is lost and at the same time the family and kin of the deceased are brought into distress. The effect of suicide reaches society. Therefore it is a very important question (Tao Menghe 1919: 15).

Tao Menghe finds that the suicide of Liang Ji was purely an act of his own will and considerations, having as such no social implications and thus no moral implications. Tao argues that traditionally suicide in China was not an act of an individual but an act performed out of consideration for human relations and alliances among the living and the dead, including traditional notions of chastity and loyalty to ruler, husband and dynasty. Tao refers to these traditional inter-human relations as 'formalism' (xingshi zhuyi 形式主義), a social practice that served as a model for individuals to emulate. He argues that because of the severe social implications of this practice, it is to be morally condemned (Tao Menghe 1919: 16). Tao Menghe concludes that there are no moral implications of suicide per se, and a positive or negative moral judgement may only be introduced in cases of suicide when we judge the social implications of each case:

Whether or not suicide is in line with morality (daode 道德), we need to make a judgement with regard to whether the social 
attitude (shehui taidu 社會態度) goes along with or is contrary [to the situation] (Tao Menghe 1919: 14).

Tao Menghe is obviously very critical of traditional practices of loyalty suicide in China. He does not favour the introduction of any new moral code, but argues for the absolute autonomy and freedom of the individual. He is also explicit on the primary role of the individual in relationship to the state. He is very upfront on the role of morality, however, which he attaches to social implications. He argues that morality does not issue forth from the innate autonomy of the individual, as Immanuel Kant has argued, but from the social effects of one's actions, bearing witness to the effects of (foreign) sociological theory entering the arena of morality debates in China. Tao also argues in favour of individual activism for political, social or economic causes, even if that means offering up one's life. To die in one's active struggle for a cause should, however, only be the unforeseen and unsolicited outcome of one's struggle and not the means with which to fight for a cause (Tao Menghe 1919: 17-18). Tao Menghe is, as a sociologist and university teacher of the May Fourth era, an advocate of the individualism so distinctive of the period and an opponent of traditional ethics. His sociological interpretation of morality does, however, tend to attach the individual to a social cause rather than to the infallible autonomy of the individual.

Morality and the position of the individual in relation to society are precisely the points in Tao Menghe's article that Liang Ji's son Liang Shuming raises in his open letter to Chen Duxiu and Tao Menghe in the April edition of Xin qingnian. Liang Shuming engages in this debate both from the position as the son of Liang Ji but probably even more so from the position of a philosopher, a nationalist, a political activist and later a proclaimed New Confucian, teaching Indian philosophy at Beijing University at this time. Liang distinguishes in his article between the motivations and the effects upon society when defining individual actions. Actions that are motivated purely within the individual and with immediate effects only upon the individual may be called individual actions. If either the motivation or the effect of the act lies beyond the individual, the act is not defined as an individual action, according to Liang. In terms of suicide, the 
immediate effect will always be on the individual. ${ }^{15}$ The motivations for suicide may, however, be either within the individual or in society at some level. Acts of suicide that are motivated solely by the individual himself may be called individual actions, thus at a level where the individual is autonomous from society. When discussing the moral aspects of suicide, Liang argues, contrary to Tao Menghe, that moral judgements are not to be based on the effects upon society but rather on the motivations of the individual. Liang Shuming suggests that in every individual there is an 'innate moral quality' (daode de suzhi 道德的素質) at the basis of one's individual motivations. This 'innate moral quality' is often expressed in a person's intellect, rationale and sentiments. A person with a superior 'innate moral quality' will perform morally superior actions and vice versa. The specific moral standards at different times and in different places may vary but the basic substance of morality inherent in 'innate moral quality' is constant. According to Liang, moral judgements are thus not related to the effects upon society, but to the innate moral quality at the basis of the motivations of the individual.

May moral judgements not be applied on individual actions? That is not the case. Individual actions can also be judged according to standard of morality (Liang Shuming 1919: 428).

Therefore, moral judgements may also be raised in cases of purely individual actions such as suicide motivated by the individual himself (Liang Shuming 1919: 427-428).

Liang Shuming does not disagree with Tao Menghe on the basic principles of individual freedom and independence in relationship to society. They do, however, disagree on one central point in the relationship between individual and society, namely on the role of morality. Where Tao attaches social responsibility to the morality of the individual by attaching moral judgement to the effects of individual actions upon society, Liang detaches individual morality from its social implications. To Liang Shuming, morality is latent in every individual and judgements are related to latent morality and not

15 Liang Shuming does not raise questions regarding the secondary effects upon the immediate family of the deceased. 
to its social implications. Both Tao and Liang are typical exponents of the kind of liberalism typical of May Fourth China. Liang, however, goes further than Tao in detaching individual autonomy from social implications and responsibility displaying the generational gap between these two generations of May Fourth intellectuals.

The last direct contribution to the debates on Liang Ji's suicide came from the pen of $\mathrm{Xu}$ Zhimo, a well-known essayist and intellectual in early republican China. When he wrote his essay on Liang's suicide, seven years had passed since the event at Jishuitan. $\mathrm{Xu}$ opened his essay by asking whether or not Tao Menghe had been right in expressing doubts about the effect upon the public of Liang Ji's death. Had his suicide in any way been a warning and a wake-up call for the new generation? Xu Zhimo presumes that what people remember of his suicide is Liang Ji's allegiance to the Qing. In 1925, the Qing was already a distant memory in China's past, and Liang Ji's loyalty to the Qing court appeared obsolete at that time. Xu, however, puts more emphasis on the personal and spiritual aspects of Liang's suicide, claiming respect for his contributions during his life and his choice (of suicide) as an individual.

Therefore, I feel that we cannot but show admiration for Liang Juchuan's suicide, precisely because what we admire is not the purity of his suicidal action in itself but the spirit that this matter expresses (Xu Zhimo 1925: 194).

Tao Menghe criticised Liang for wasting his life for a lost cause, judging him by the social effects of his action, while Xu Zhimo claims that Tao has neglected the spiritual life of the individual and a people/nation that outlasts the physical life of the individual on earth. $\mathrm{Xu}$ Zhimo criticises all those who judge the morality of suicide by social standards, and argues in favour of the individual and national spirit (jingshen 精神) of such actions. He even goes so far as to ridicule a number of known cases of men who were determined to commit suicide but were deterred from doing so by wives and families - Xu criticizing them for lacking the commitment and spirit to go ahead with their desired purpose. "This was the complete victory of the minds of the sociologists, they would not waste a human life in vain" (Xu Zhimo 1925: 195). Xu Zhimo's assault on the position of 
Tao Menghe illuminates what I have called the difference between the collectivist and the individualist-position in terms of the morality of the individual. Xu Zhimo, much in line with Liang Shuming, argues in favour of a moral judgement based on the spirit of the determination and action of the individual representing the individualist-position, while at the same time identifying Tao Menghe as a 'sociologist' (shehuixuezhe 社會學者), in what I have called the collectivistposition, judging the morality of the individual by the effects of actions on society. ${ }^{16}$

\section{The debate on the suicide of Lin Deyang}

The second of the cases of suicide in 1918-19 that set off debates on perceptions of the relationship between individual and society, morality, suicide, individualism and social responsibility in China is the suicide of Lin Deyang (林德揚) on November 17, 1919. Lin was at the time a Beijing university student in his third year. In the spring of 1919 he was recovering from a lung ailment spending time for rehabilitation at Xishan (西山) outside of Beijing. When he learned about the events in Beijing around May fourth, 1919, he rushed back to the city to take part. As he argued that China could redeem her national respect only through concrete action, he opened a small shop in Beijing selling only Chinese products and boycotting the import of Japanese merchandise. After a short time, his business ran into difficulties, and he asked friends to help him take care of the shop while he himself apparently became depressed and worried about (some) matters. He also lost his engagement in political affairs, according to his friend and fellow student Luo Jialun (羅家倫, style Luo Zhixi 羅志希) (1897-1969). Then, on November 17, he took off his clothes, jumped into the pond in Sanbeizi garden (三貝子花園) and drowned. The previous evening, he had prepared three letters to his mother and brothers, making arrangements for his family after his death. He had also made a report of all his outstanding debts, and how

16 Xu Zhimo's assault on Tao Menghe's article also set off a series of arguments between the two in the supplement to Chenbao (晨報), reprinted in Zhimo quanji. 
his accounts should be settled. There are no indications that his suicide in any way was related to his disease (Luo Zhixi 1919: 346347). Following Lin Deyang's suicide a series of articles in the Beijing daily newspaper Chenbao (晨報) discussed issues related to morality, suicide, individualism and social responsibility. The first of these is an article printed in Chenbao on November 19, entitled "Is This a Youth Committing Suicide or Is It Society Killing a Youth?" ("Shi qingnian zisha haishi shehui sha qingnian" 是青年自殺還是社會殺青年), written by Luo Jialun, Lin's friend and fellow student at university, later central among the student activists around the Xinchao periodical and Xinchao society. The second of these articles by Beijing University professor Jiang Menglin (蔣萝麟) (1886-1964) appeared with the title "The Suicide of Beijing University Student Lin Deyang" ("Beida xuesheng Lin Deyang jun de zisha” 北大學生林德揚君的自殺) in Chenbao on November 21. The third of these articles carried the title "Questions Related to Youth Detesting the World and Committing Suicide" ("Qingnian yanshi zisha wenti”青年厭世自殺問題), and was signed by Li Shouchang (李守常), the pen name of Li Dazhao. This article by Li Dazhao appeared with reprints of the two preceding Chenbao articles in the December 1919 issue of Xinchao, the Beijing University student periodical. These articles in Xinchao were followed by an extensive article on the topic of suicide entitled "On Suicide" ("Lun zisha" 論自殺) signed Chen Duxiu published in the January 1, 1920 issue of Xin qingnian. ${ }^{17}$ Articles in the Shanghai periodical The Eastern Miscellany (Dongfang zazhi 東方雜誌) in 1921 on suicide may also have been prompted by these debates in the Beijing press, without specifically relating the debate to these cases taking place in Beijing. ${ }^{18}$

Luo Jialun is exclusively engaged in the conditions for the life of the individual in his analysis of Lin's suicide, and clearly fits into the category that I have called the individualist-position. He does not express views on the life of the individual in terms of the individual

17 A short exposition of the debate on Lin Deyang's suicide is also found in Schwarcz 1986: 73-74.

18 “Suicide among Youth” (“Qingnian zhi zisha”青年之自殺) by Jian Meng (健孟) in the December 10, 1921 issue of The Eastern Miscellany and "Lodge's Suicide Theory” (“Luoqi de zishalun”洛奇的自殺論) by Qiao Feng (喬峯) in the December 25, 1921 issue of The Eastern Miscellany. 
simply being a cog in the wheel of society, but rather addresses the question of suicide from the position of the individual: what are the conditions for the individual in present day Chinese society? The arguments that we find in many of the contributions to the analysis of Lin Deyang's death is related to the term yanshi (厭世), 'detesting the world', signifying an attitude of the individual who finds the conditions for the individual in society unbearable and unacceptable. Luo claims that the social and political conditions in China in 1919 drove people into personal despair, and that many people are likely to consider committing suicide in such a situation, whereas in foreign countries people mainly commit suicide for reasons of (unhappy) love, he claims. Luo Jialun, speaking from the viewpoint of the student generation in China in 1919, suggests three main reasons why society in China drives people into despair and suicide. The first is the lack of opportunities to develop one's creativity. Life is nothing but struggle from morning till night, wearing on people's mental health. People need to express creativity in order to balance between emotions and ambitions. The second reason is the lack of social relations outside the family, in particular relations between men and women. Life is dull and without flavour, and relationships to close friends outside one's immediate family are necessary in order to solve many personal dilemmas and difficulties. Women in particular are good at solving personal dilemmas and talking men out of suicidal depressions, reflecting ongoing debates on gender equality and relations between men and women in Chinese society. The third reason is the change in Chinese youth's 'view on life' (renshengguan 人生觀) that occurred with the May Fourth Movement. Old ideals and views on life have become redundant and been renounced, while new ideas and ideals for new morality have yet failed to create a stable basis for new views on life. The 'mental state of doubt' (huaiyi de xinli 懷疑的心理) in individuals that is the result of this transitional state of society is a major cause for high suicidal rates (Luo Zhixi 1919: 347-348). Luo Jialun claims that higher suicide rates are to be expected in a modernising society where the individual is engaged in social and political matters. When an individual wholeheartedly works for the improvement of society to no avail, then suicide is often the only resolution at a personal level. This spirit and resolution should be 
admired and suicide should not be regarded as immoral, according to Luo.

Anyone in this world who does not have a resolute heart and is not willing to offer one's life for a cause, will be unable to make a contribution in life (Luo Zhixi 1919: 348).

Luo concludes that society killed Lin Deyang. He sees the society of China in 1919 as a callous society for the individual, and indicates that the individual takes precedence over society as such, much in line with what may be anticipated as an argument claimed by the student generation of intellectuals at the eve of the May Fourth Movement, and by an intellectual later attached to ideas in defence of individual autonomy (Schwarcz 1986: 106-107).

Beijing University professor Jiang Menglin argues in line with the student Luo Jialun, pointing to three social causes that affect suicide rates; 'attitudes of doubt' (duiyu shishi huaiyi 對於事事懷疑), 'freedom of thought' (sixiang ziyou 思想自由), and 'views on life' (renshengguan 人生觀). He disagrees with Luo on one central and indicative point, however, namely on the question about the morality of committing suicide. Jiang claims that Heaven has created every single individual. Thus every individual has a duty to protect his own life and it would be a sin (zui 罪) to act against the will of Heaven, apparently borrowing his argument from Christian reflections on the value of life in itself. When Luo Jialun blames society for the death of Lin Deyang, Jiang Menglin maintains that the individual also has a responsibility to change society in order to better conditions for the individual. If persons who are discontented with the ways society develops prefer suicide as a solution, then society is never going to improve conditions for the individual. Jiang Menglin concludes that the suicide of Lin was a sin against humanity and society because he renounced his struggle and gave in to his desire to escape life itself. Man must struggle to overcome this difficult transitional phase in the development of society in order for China to reach into a 'new existence' (xin tiandi 新天地) where a 'new life' (xin shenghuo 
新生活) of the individual is the primary goal (Jiang Menglin 1919). ${ }^{19}$ Jiang clearly places more emphasis on the moral responsibility of the individual towards society and life itself, compared to the arguments in the article by Luo Jialun. Jiang also argues for the primary interest of the individual, but inclines towards what I have called a collectivist-position, attaching the moral value of the individual to his task towards society at large. Jiang indicates that the individual must sacrifice his personal desires (for death) on behalf of society in order to pave the way for a new life of the (collective) individual for future generations. Morality lies in one's contribution to society and not in the autonomy, independence and freedom of choice of each individual, according to Jiang Menglin, presenting a mix of Chinese traditional ethics, Western sociological influence (mainly John Dewey) and Christian perspectives on the sin of committing suicide so typical for this generation of teacher intellectuals in May Fourth China.

Li Dazhao, in his article in Xinchao, responds to the arguments by Luo Jialun and Jiang Menglin, discussing suicide in a context of social development in general. $\mathrm{Li}$ also argues that the increasing number of suicides in China caused by these youth 'detesting the world' is consistent with a similar trend in the West, where an increasingly complex and demanding society drives more young people into various disconcerting circumstances, leaving them with suicide as a preferred option in life. It is tempting to read the word 'modernity' from Li Dazhao's analysis and arguments but that is not a term he applies himself. Li Dazhao refers in general terms to the nineteenth century as the 'epoch of suicide' (zisha shidai 自殺時代) and suicide as the 'disease of this epoch' (shidaibing 時代病) ${ }^{20}$ (Li Dazhao 1919: $352-353)$.

19 See Lee 2001: 31-32 for a discussion of the use of the term 'new' (xin 新) in the May Fourth discourse.

20 Li Dazhao refers to figures for suicides in China from 1907 showing a similar growing trend in numbers (Li Dazhao 1919: 352-353). Similar figures for the rising suicide rates may also be found for the major Chinese cities of early twentieth century China in various sources mainly gathered from reports in contemporary newspapers. 
A society where suicide rates are high is certainly a gloomy and depressive society. Behind the phenomenon of suicide there are indeed many of the deficiencies of that society (Li Dazhao 1919: $351)$.

$\mathrm{Li}$ argues that as long as an individual does not directly harm society or lead it astray, he is in principle free to determine the acts of his own life based on the right of freedom over one's own life. In terms of the morality of the individual, one may express one's opinion on others' views on life and possibly lead young people on a way to improvement in life, but we may not pass a judgement on the morality of suicide, neither may we pass judgements on the sinfulness of suicide, according to Li Dazhao. We may only pass judgements on actions that directly harm society or lead others astray through acts of suicide (Li Dazhao 1919: 351). Li Dazhao expresses some sympathy with those individual youths in China who chose to take their own lives in a society that put immense pressure upon them at the time of the May Fourth. His main attitude, however, clearly inclines towards blaming them for escaping the challenges of life and society. Rather than giving up on living in these challenging times, Li claims, they should have gathered their resources and courage and struggle for a new life in order to remedy the deficiencies of society (Li Dazhao 1919: 355-356). Along with Jiang Menglin, Li Dazhao, as a member of the teacher generation of intellectuals at this time, is primarily concerned with social problems and subordinates the desires and autonomy of the individual to the causes of social development. Li argues unambiguously that questions about morality and sin as such are irrelevant when discussing the rights and wrongs of suicide. We may pass judgement on their views on life and even lead them on a way to a better personal life. But when we discuss the rights and wrongs of suicide, it should be with the benefits of society at large in mind.

Where Li Dazhao clearly argues for an emphasis on the social aspects of the effects of suicide, which I have referred to above as a collectivist-position, Chen Duxiu, in his article on the suicide of Lin Deyang, goes one step further in his condemnation of suicide and in his emphasis on the social responsibility of individual action. Chen Duxiu argues in favour of the value of the 'physical self' (wuzhi de 
ziwo 物質的自我) that expands out to the 'extended self' (ziwo guangda 自我廣大) which is represented by one's descendants, the nation and humanity at large. The 'spiritual self' (jingshen de ziwo 精神的自我) expands further to make human history. The sum of the evidences of individual lives is what makes 'existence' (you 有), which is reality. This reality is opposed to 'emptiness' (kong 空) (Chen Duxiu 1920: 9). This existence of the individual as a part of the whole is the theoretical claim substantiating Chen's argument why each individual must choose life instead of death, choose 'existence' instead of 'emptiness'. Every single individual has his intrinsic value in his existence as a part of the 'extended self'. This is why Chen characteristically presents suicide as a social problem and addresses its solutions. In line with the arguments discussed above, Chen in 1920 identified two causes of suicide that represent a socially destructive trend: 'perilous life views' (weixian de renshengguan 危險的人生觀), and 'detesting the world' (yanshi 厭世) (Chen Duxiu 1920: 10). The remedy of this socially destructive trend is to be found in expelling the 'primary doubt from human life' (rensheng genben de huaiyi 人生根本的懷疑). Any stable society is based on two primary forces, according to Chen: the structural organisation of society and the morality of the individual. Opposing forces in such stable societies will be excluded, and these individuals may turn to suicide. These forces will never be able to topple the constructive development of stable and healthy societies. But a society should also make sure that these opposing forces, these potentially 'renewing elements' (xinsheng fenzi 新生分子), as Chen terms them, are given a basis for existence, since they may in turn make up the forces that can renew society at times of great change. These oppressed elements have a duty to pursue their cause for these reasons and not turn to unconstructive solutions, such as suicide, precisely because they may be the vigour for change at the next turn of society. A society needs these opposing forces. Without them any society will stagnate, according to Chen Duxiu in 1920 (Chen Duxiu 1920: 11). Lin Deyang and others in China who have chosen suicide rather than a life of struggle represent these elements that would have had the potential to renew China. That is why it is incumbent for such people to choose life instead of death, 'existence' instead of 'emptiness', struggle rather than escape. They need to see society from an objective perspective 
and not subjectively from their own situation, Chen Duxiu argues. These cases of suicide have a sense of value because they are motivated by social challenges. But they are indeed not examples of society taking the lives of these young people, as argued by Luo Jialun. They are killed by their own (weak) mental state. That is how Chen Duxiu interprets these cases (Chen Duxiu 1920: 11-12). We recognise this emphasis on common welfare in a contemporary debate in Xinchao where Fu Sinian (傅斯年) (1896-1950) and Chen Duxiu both argue in favour of "the free development of the individual for the common welfare" (Schwarcz 1986: 98).

Chen Duxiu further presents an interesting theory of intellectual historical development in this article published in 1920. He divides history into three phases; one 'ancient way of thinking' (gudai sichao 古代思潮), one 'recent (modern) way of thinking' (jindai sichao 近代思潮), and one 'most recent way of thinking' (zuijindai sichao 最近代思潮). In ancient times there were 'no perceptions of the self' (wuwo 無我) and society was ruled by individuals and not by states. In recent times (modernity) 'individualism' (or 'egoism') (weiwo 唯我) has been important and society has been ruled by the state. In what Chen calls 'most recent times' the 'extended self' is the dominant perception of the self, and society is to be ruled by society itself and not by the state. The 'most recent times' were at their height in Europe in the second half of the nineteenth century, while China is still only approaching this stage (Chen Duxiu 1920: 12-13). Chen Duxiu is anticipating that the development of individualism in China in 1920 is an intermediate stage in the modern era leading towards a kind of socialism where the individual vests a primary interest in society at large. This is where Chen sees the hope for Chinese society. We notice that the individual for Chen has outplayed its role and its extended form, the 'extended self', is becoming the basis for moral evaluations of right and wrong. Morality to Chen is the standards with which the individual acts towards society, where the objective of society rather than the absolute value of the individual is the primary yardstick. Chen Duxiu expresses no admiration for the autonomy of the individual in 1920 except as a stage in history. That stage in history will lead to an elevated state of the relationship between the individual and society, with morality of the individual as a means and not as an end. Suicide as a social phenomenon is a symptom of great 
social transformations but otherwise only a sign of the weakness of the individual, and an unwillingness to submit to a higher cause. Clearly, Chen Duxiu represents at this time a strong inclination towards, or maybe even a return to, what I have called the collectivistposition, anticipating the blooming of socialism in China and his own involvement in the establishment of the Chinese Communist Party the following year.

Benjamin Schwartz has described Chen Duxiu as one of the intellectuals in China at this time who searched the West for solutions to China's social and moral problems - and "approached western civilization with a strongly anti-traditional predisposition" (Schwartz 1951: 64). Chen's passionate involvement with China's challenges and problems, ready to find the best solution for every new challenge, rather than presenting solutions in deeply rooted and systematic theoretical constructions, has made him a man liable to criticism and suspicion with regard to his motivations. Schwartz argues, however, that Chen's ability to abandon previously held positions made him a man of profound significance in a changing China of the twentieth century (Schwartz 1951). Chen Duxiu's contribution to the debate on suicide signifies precisely the changing concept of the relationship between individual and society in the early $1920 \mathrm{~s}$, where the fundamental position of the individual in social relations typical of the May Fourth Era was soon remoulded into socialist perspectives, attaching the morality and social responsibility of the individual to the aims of the collective good.

\section{Concluding remarks}

The modern era impelled by intellectual, political and social changes in China around the May Fourth Movement installed a sense of freedom, independence and autonomy of the individual in the Chinese intellectuals of the time. Suicide became interpreted as a reaction at different levels to the challenges in the personal and social life of the individual. Contrary to more traditional perceptions, when suicide primarily functioned as a prescribed response to dilemmas of loyalty and chastity, suicide in the May Fourth Era was interpreted as a choice and reaction of the individual as an autonomous being. Generally, 
suicide was tolerated, although not encouraged, at a personal and individual level related to the absolute value of the individual per se. Morality was for many but not for all of the intellectuals taking part in this debate, however, primarily a question of the social responsibility of the individual. In this perspective, suicide was morally unacceptable, a perspective mainly held by the teacher generation of May Fourth intellectuals. Others, again, related morality to the primary autonomy of the individual and tolerated suicide as an expression of the free will of the autonomous individual, a view mainly held by the student generation of May Fourth intellectuals. Students of the May Fourth generation did not seek personal fulfilment in the future prospects of Chinese society. These May Fourth "radicals of the student generation were less content with sacrificing themselves for the future" (Schwarcz 1986: 109). They were concerned about present conditions for man and for themselves as individuals. The moral condemnation of suicide was apparently gaining acceptance among socialist intellectuals in China in the early 1920s. We observe that Durkheim's theory of a linear development from approval towards disapproval of suicide with the advent of modernity, and an emphasis on the dignity and sacredness of the individual, does not fully apply in the Chinese case. In fact, it seems that the strongest advocates of individualism in China at the time argued, contrary to Durkheim, that the sacredness of the individual was ultimately expressed not in a condemnation of the act of suicide but by acknowledging that autonomous individuals enjoyed complete freedom of choice - also in matters of life and death.

\section{References:}

Alitto, Guy S. 1986. The Last Confucian: Liang Shu-ming and the Chinese Dilemma of Modernity. Berkeley: University of California Press.

Anonymous. 1881. “Lun qingsheng” (論輕生). In: Shenbao (申報), 10 July, 1881, p. 1.

Anonymous. 1906. "Lun zisha fei zhishi suo yichu" (論自殺非志士所宜出). In: The Eastern Miscellany (Dongfang zazhi 東方雜誌), vol. 11, November 1906, pp. 221-222. 
Bauer, Wolfgang. 1985. "The hidden hero: Creation and disintegration of the Ideal of Eremitism". In Munro, Donald J., ed. Individualism and Holism: Studies in Confucian and Taoist Values. Ann Arbor: The University of Michigan, pp. 157-197.

Bonner, Joey. 1986. Wang Kuo-wei: An Intellectual Biography. Cambridge, Mass.: Harvard University Press.

Chen Duxiu 陳獨秀. 1919. “Duiyu Liang Juchuan xiansheng zisha zhi ganxiang” (對於梁巨川先生自殺之感想). In: Xin qingnian (新青年), 6:1, pp. 19-20.

Chen Duxiu陳獨秀. 1920. ”Zisha lun”(自殺論). In: Xin qingnian (新青年), 7:2, pp. 1-13.

Chen, Xiaoming. 2007. From the May Fourth Movement to Communist Revolution: Guo Moruo and the Chinese Path to Communism. New York: State University of New York Press.

Dirlik, Arif. 1989. The Origins of Chinese Communism. New York and Oxford: Oxford University Press.

Doleželová-Veligerová, Milena and Oldřich Král, eds. 2001. The Appropriation of Cultural Capital: China's May Fourth Project. Cambridge, Mass. \& London: Harvard University Press.

Durkheim, Émile. (1897) 1951. Suicide. Free Press.

Eberhard, Wolfram. 1967. "Suicide in short stories." In: Guilt and Sin in Traditional China. Berkeley and Los Angeles: University of California Press, pp. 94-105.

Elvin, Mark. 1984. "Female virtue and the state in China." In: Past and Present, No. 104 (August 1984), pp. 111-152.

Fogel, Joshua A. and Peter G. Zarrow, eds. 1997. Imagining the People: Chinese Intellectuals and the Concept of Citizenship, 1890-1920. New York and London: M. E. Sharpe.

Hsieh, Andrew C. K. and Spence Jonathan D. 1981. "Suicide and the family in pre-modern Chinese society." In: Kleinman, Arthur and Lin, Tsung-Yi, eds. Normal and Abnormal Behavior in Chinese Culture. Dordrecht, Boston and London: D. Reidel Publishing Company, pp. 29-47.

Huang, Philip C. 1972. Liang Ch'i-ch'ao and Modern Chinese Liberalism. Seattle: University of Washington Press.

Jian Meng 健孟. 1921. “Qingnian zhi zisha” (青年之自殺). In: The Eastern Miscellany (Dongfang zazhi 東方雜誌), vol. XVIII, no. 23, December 10, 1921, pp. 2-4. 
Jiang Menglin 蔣萝麟. 1919. "Beida xuesheng Lin Deyang jun de zisha” (北大學生林德揚君的自殺). In: Xinchao (新潮), 2:2, pp. 349-350.

Karl, Rebekka E. and Peter Zarrow, eds. 2002. Rethinking the 1898 Reform Period: Political and Cultural Change in Late Qing China. Cambridge, Mass. and London: Harvard University Press.

Lee, Leo Ou-fan. 2001. "Incomplete modernity: Rethinking the May Fourth intellectual project.” In: Doleželová-Veligerová, Milena and Oldřich Král, eds. 2001. The Appropriation of Cultural Capital: China's May Fourth Project. Cambridge, Mass. and London: Harvard University Press, pp. 31-65.

Liang Qichao 梁啟超. 1998. Xinminshuo 新民說. Zhengzhou: Zhongzhou guji chubanshe 中州古籍出版社.

Li Dazhao 李大釗. 1919. "Qingnian yanshi zisha wenti" (青年厭世自殺問題). In: Li Dazhao wenji 李大釗文集. Beijing: Renmin chubanshe 人民出版社, 1954, xiajuan (下卷), pp. 153160.

Li Shouchang 李守常 (pen name for Li Dazhao 李大釗). 1919 . "Qingnian yanshi zisha wenti” (青年厭世自殺問題). In: Xinchao (新潮), 2:2, pp. 351-356.

Liang Shuming 梁漱溟. 1919. "Liang Juchuan xiansheng de zisha" (論巨川先生的自殺). In: Xin qingnian (新青年), 1919, 6:4, pp. 427-432.

Lindell, Kristina. 1973. "Stories of suicide in ancient China. An essay on Chinese morals." In: Acta Orientalia, vol. 35. Copenhagen: Munksgaard, pp. 167-239.

Liu Changlin 劉長林 and Qian Jinjing 錢錦晶. 2003. “Lun Wusi sixiangjia dui zisha xianxiang de yanjiu" (論五四思想家對自殺現象的研究). In: Shixue yuekan (史學月刊) 6,pp. 59-68.

Liu, Lydia. 1995. Translingual Practice: Literature, National Culture, and Translated Modernity - China 1900-1937. Stanford: Stanford University Press.

Lu, Weijing. 2008. True to Her Word: The Faithful Maiden Cult in Late Imperial China. Stanford: Stanford University Press.

Luo Zhixi 羅志希. 1919. "Shi qingnian zisha haishi shehui sha qingnian” (是青年自殺還是社會殺青年). In: Xinchao (新潮), 2:2, pp. 346-348. 
Marra, Realino and Marco Orrù. 1991. "Social images of suicide." In: The British Journal of Sociology, vol. 42, no. 2 (June 1991). The London School of Economics and Political Science, pp. 273-288.

Ropp, Paul S. 2001. "Passionate women: Female suicide in late Imperial China - Introduction.” In: Nan Nü 3:1. Leiden: Brill Academic Publishers, pp. 3-21.

Qi Weiping 齊衛平. 1998. “Wusi shiqi Zhongguo shehui zhuanxing yu zisha xianxiang” (五四時期中國社會轉型與 自殺現象). In: Minguo chunqiu (民國春秋), vol. 3, pp. 49-51.

Qiao Feng 喬峯. 1921. “Luoqi de zishalun” (洛奇的自殺論). In: The Eastern Miscellany (Dongfang zazhi 東方雜誌), vol. XVIII, no. 24, December 25, 1921, pp. 67-70.

Schwarcz, Vera. 1986. The Chinese Enlightenment. Intellectuals and the Legacy of the May Fourth Movement of 1919. Berkeley: University of California Press.

Schwartz, Benjamin. 1951. "Ch'en Tu-Hsiu and the acceptance of the modern West." In: Journal of the History of Ideas, vol. 12, no. 1 (January 1951), pp. 61-74.

Shi Hanze 石涵澤. 1930. Zisha wenti (自殺問題). Shanghai: Huatong shuju 華通書局.

Simpson, Miles E. and George H. Conklin. 1989. "Socioeconomic development, suicide and religion: A test of Durkheim's theory of religion and suicide". In: Social Forces, vol. 67, no. 4 (June 1989). University of North Carolina Press, pp. 945-964.

Sun, Lung-kee. 2008. "The other May Fourth: Twilight of the old order." In: Chou, Kai-Wing et al., eds. Beyond the May Fourth Paradigm: In Search of Chinese Modernity. Lanham: Lexington Books, pp. 271-292.

Svarverud, Rune (forthcoming). "Individual self-discipline and collective freedom in the minds of Chinese intellectuals." In: The Rising Chinese Individual. Copenhagen: NIAS Press.

Tao Menghe 陶孟和 (Tao Lugong 陶履恭). 1919. “Lun zisha” (論自殺). In: Xin qingnian (新青年), 6:1, pp. 12-18.

Theiss, Janet. 2001. "Managing martyrdom: Female suicide and statecraft in Mid-Qing China." In: Nan Nü 3:1. Leiden: Brill Academic Publishers, pp. 47-76. 
Theiss, Janet M. 2004. Disgraceful Matters: The Politics of Chastity in Eighteenth Century China. Berkeley: University of California Press.

Wagner, Rudolf. 2001. "The canonization of May Fourth." In: Doleželová-Veligerová, Milena and Oldřich Král, eds., The Appropriation of Cultural Capital: China's May Fourth Project. Cambridge, Mass. and London: Harvard University Press, pp. 66120.

Weston, Timothy B. 2004. The Power of Position: Beijing University, Intellectuals, and Chinese Political Culture, 1898-1929. Berkeley: University of California Press.

Witke, Roxane. 1967. "Mao Tse-tung and suicide in the May Fourth era." In: The China Quarterly, No. 31 (July-September 1967). School of Oriental and African Studies, pp. 128-147.

Xu Zhimo 徐志摩. 1925. "Lun zisha” (論自殺). In: Zhimo quanji (志摩全集). Taibei: Zhengwen chubanshe 正文出版社, 1969 (originally published in a supplement to Chenbao 晨報 October 12 1925), pp. 192-198.

Yuzhi 愉之 (tr. from American). 1917. "Zisha zhi yuanyin yu qi fangzhi zhi fa” (自殺之原因與其防止之法). In: The Eastern Miscellany (Dongfang zazhi 東方雜誌), June 1917, pp. 63-65.

Zheng Qingpo 鄭清坡 and Li Zidian 李自典. 2005. “Shilun Li Dazhao dui minchu zisha xianxiang de yanjiu" (試論李大釗對民初自殺現象的研究). In: Guizhou shehui kexue (貴州社會科學), vol. 195, no. 3, May 2005, pp. 160-164. 